\title{
ON ODOUR EMISSION RATE FROM THE WORKING AREA OF A MUNICIPAL SOLID WASTE LANDFILL IN CHINA
}

\author{
Ning QIANG, Zhaohai LI and Tao LIU*
}

Institute for Environmental Science and Technology, Tongji University, Shanghai 200092, China. *Corresponding author: liutao45@163.com

(Received May 2018; accepted July 2018)

Key words: municipal solid waste landfill, working area, non-point source, odour emission rate, wind tunnel

\begin{abstract}
To investigate the odour emission rate from the surface of a municipal solid waste landfill working area in China, a wind tunnel sampler was used to measure the emission rates of volatile organic compounds (VOCs), $\mathrm{H}_{2} \mathrm{~S}$ and odour units. The results showed that the odour emission rate from the non-point source landfill is closely connected with the environmental temperature and the velocity of surface sweeping. In summer, the emission rates of VOCs (measured by PID as isobutylene), $\mathrm{H}_{2} \mathrm{~S}$ and odour units are $385-680 \mu \mathrm{g} \bullet\left(\mathrm{m}^{2} \bullet \mathrm{s}\right)^{-1}, 4-7 \mu \mathrm{g} \bullet\left(\mathrm{m}^{2} \bullet \mathrm{s}\right)-^{-1}$, and 46.5-136 OU $\bullet\left(\mathrm{m}^{2} \bullet \mathrm{s}\right)^{-1}$, respectively; in winter, the emission rates are $140-280 \mu \mathrm{g} \bullet\left(\mathrm{m}^{2} \bullet \mathrm{s}\right)^{-1}, 0.5-1.8 \mu \mathrm{g} \bullet\left(\mathrm{m}^{2} \bullet \mathrm{s}\right)^{-1}$, and $8.5-16.2$ $\mathrm{OU} \cdot\left(\mathrm{m}^{2} \bullet \mathrm{s}\right)^{-1}$, respectively. The emission rate measured in the high temperature season is nearly 6 times higher than that in the low temperature season. In the experimental wind sweeping velocity range of 0.6 to $4 \mathrm{~m} \cdot \mathrm{s}^{-1}$, there is a linear relationship between the emission rate and the wind sweeping velocity. The continuous sweeping experiment shows that the emission rate measured with clean air sweeping is the greatest possible emission rate, which needs to be adjusted when used to estimate the odour concentration in some cases, such as if the sampling time exceeds 10 min or when estimating an area emission.
\end{abstract}

Key words: relleno municipal de residuos sólidos, área de trabajo, fuente no puntual, tasa de emisión de olores, túnel de viento

\section{RESUMEN}

Para investigar la tasa de emisión de olores desde la superficie de un relleno de residuos sólidos en China, se utilizó un muestreador de túnel de viento para medir la tasa de emisión de compuestos orgánicos volátiles (VOCs, por sus siglas en inglés), H2S y unidades de olor. Los resultados muestran que la tasa de emisión de olores desde el relleno considerado como fuente no puntual se relaciona fuertemente con la temperatura ambiental y la velocidad de barrido de viento de la superficie. En el verano las tasas de emisión VOCs (medidas por PID como isobutileno), H2S y unidades de olor (OU, por sus siglas en inglés) fueron 385-680 $\mathrm{mg}\left(\mathrm{m}^{2} \bullet \mathrm{s}\right)-1,4-7 \mathrm{mg}\left(\mathrm{m}^{2} \bullet \mathrm{s}\right)-1$ y $8.5-16.2 \mathrm{OU}$ $\left(\mathrm{m}^{2} \bullet \mathrm{s}\right)-1$ respectivamente. La tasa de emisión medida durante la estación con temperatura más alta es cerca de seis veces mayor que la determinada en la estación de temperatura baja. En el rango experimental de velocidad de barrido de viento de 0.6 a $4 \mathrm{~m}^{2} \bullet \mathrm{s}-1$ hay una relación lineal entre la tasa de emisión y la velocidad de barrido del viento. 
El experimento de barrido continuo muestra que la tasa de emisión con aire de barrido limpio es la mayor posible, la que necesita ser ajustada cuando se usa para estimar la concentración del olor en algunos casos, como cuando el tiempo de muestreo es mayor a 10 min o cuando se quiere estimar una área de emisión.

\section{INTRODUCTION}

Along with socioeconomic development and improved living standards, the quantity of municipal solid waste (MSW) in China has continuously been increasing in recent decades (Vicente-Molina et al, 2018, Zahan et al. 2018). In 2014, the amount of MSW transported has reached 178.6 million tons, and 107.5 million tons has been disposed for sanitation purposes, of which approximately $60 \%$ was safely disposed of in landfills ; although the significantly inadequate treatment capacities, planning and building new facilities have been contradicted because of the public concern on odour nuisance and the proportion of MSW disposed of in landfills has been declining each year, it still accounts for a high proportion (National Bureau of Statistics of China 2015, Zhao et al. 2015, Tian et al. 2013, Zhang et al. 2010, Ismail and Hanafiah 2017). Because the organic matter and moisture of MSW exhaust in many areas of China are relatively high, odour pollution, which originates from the transportation and landfill processes, has become a public hazard. Odour impact in urban areas can be very difficult to assess and control due to the inherent complexity of the urban environment, the large number of potential sources and the local smallscale variability of the dispersing wind (Pettarin et al. 2015, Usman et al. 2017). The odour pollutants that originate from a landfill site mainly come from the working face and storage piles of the landfill reservoir, which is an open fugitive surface source (Romain et al. 2008, Sironi et al. 2005, Rehman et al. 2017). Better understanding of the diffusion pattern of the surface source is the key to eliminating the odour pollution of a landfill site (Gao et al. 2017, Shen et al. 2017).

Many researchers have conducted studies on the odour pollution of MSW landfill sites, which have mainly focused on the chemical composition of landfill odour, the odour concentration of different sampling positions in landfill sites and the regional impact of the odour pollution (Capelli et al. 2008, Chiriac et al. 2009, El-Fadel et al. 1997, Romain et al. 2008, Chiriac et al. 2007, Davoli et al. 2003, Dincer et al. 2006, Fang et al. 2012, Lu et al. 2011, Zou et al. 2003, Tan et al. 2017). Besides the properties of
MSW, the amount of odour diffusion from the landfill surface source is affected by the meteorological conditions (Chiriac et al. 2009, Dincer et al. 2006, Lu et al. 2015, Yun et al. 2017). Most previous studies were based on the sampling method of instantaneous ambient air or using short-term enrichment tubes, from which the odour concentration tested is heavily influenced by the meteorological condition, and the quantity of odour diffusion from the landfill surface source is difficult to generalize or deduce (Grzeczka and Szymak 2016, Carvalho et al. 2016, Qu et al. 2017). Some previous studies determined the downwind odour concentration and used the concentration data to calculate the diffusion with a Gaussian diffusion model (Chemel et al., 2012; Nicolas et al., 2006); however, the heavy field test workload and the stability of the meteorological conditions during the testing can substantially influence the test results (Chemel et al. 2012, Nicolas et al. 2006, Xiao et al. 2017). Other researchers have also used static wind cover or wind tunnels to measure the diffusion of surface sources, such as agricultural soil, sewage surfaces and livestock farms (Capelli et al. 2009, Hudson et al. 2009, Hudson et al. 2006, Sarkar and Hobbs 2003, Sironi et al. 2006, Van der Weerden et al. 1996, Wang et al. 2001). Some researcher measured the emission rate of hydrogen sulfide from quiescent liquid surfaces to the atmosphere in the Lab (Prata et al. 2016, Razali and Said 2017). However, emission rate is fundamental information to evaluate Emission factors (EFs) and actually very little data is available for landfill fugitive emission source in China (Liu et al. 2016, Halim and Phang 2017). Moreover, there have been few studies of MSW landfills on assessing emission rates from the working face of a landfill, especially field experiments of odour, and the impact of surface wind velocity of the working surface in four seasons has not been taken into consideration in previous research (Liu et al. 2015, Sironi et al. 2005).

In this study, in the Shanghai Laogang MSW landfill, a wind tunnel was used to sample and simulate the surface wind flow on the working face. The odour concentration was measured in combination with VOCs, $\mathrm{H}_{2} \mathrm{~S}$, artificial olfactory discrimination and the air sense. The odour diffusion rate on the working surface of different seasons was measured 
during the research, combined with the area data of the working face to estimate the odour diffusion quantity of the surface source, which can be used to research the impact of different meteorological conditions on odour and provide targeted guidance to odour hazard control.

\section{MATERIAL AND METHODS}

\section{Wind tunnel sampling system}

The diffusion rate of the surface source is directly related to the surface wind and temperature. In this study, a wind tunnel system with volume adjustment and a display device was used to measure the odour diffusion rate of the MSW working surface. The scheme of the wind tunnel system is shown in Fig. 1(a):

A frequency conversion fan was used to produce the surface wind at the tunnel section with a velocity of $0-4 \mathrm{~m} \cdot \mathrm{s}^{-1}$, the grain activated carbon (GAC) tank was used to eliminate the odour in the background atmosphere, and the calibrated pressure flowmeter was used to display the wind velocity of the tunnel section. The wind tunnel was made of stainless steel, as shown in Fig. 1(b), and consisted of air inlet and outlet pipes, increase and decrease pipes, the principal part and an elbow pipe. There were three flow deflectors located in the increase pipe, making the wind flow evenly distributed at the tunnel crosssection area. The principal part was a cuboid with an opening bottom, at which a 20-millimetre-long steel

(a)

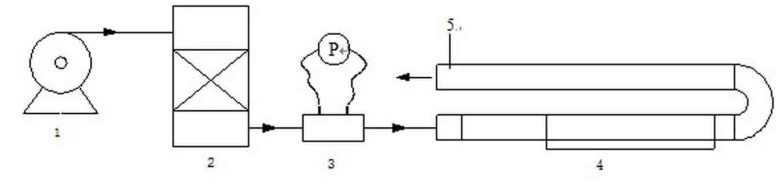

(b)

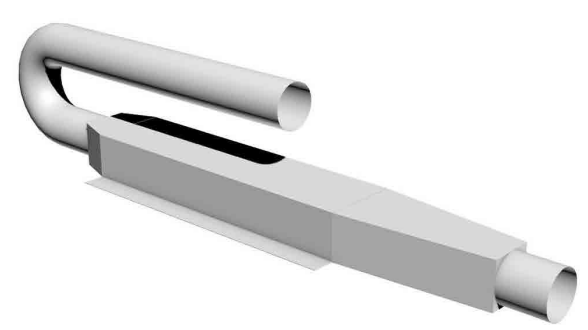

Fig. 1. (a) Scheme of the wind tunnel system (1. Frequency conversion fan; 2. GAC tank; 3. Pressure flowmeter; 4. Wind tunnel; 5. Monitoring site) and (b) Picture of the wind tunnel plate was extended to make the wind tunnel easy to stick into the MSW surface and create an airtight sweep atmosphere. There was also a 50-millimetrelong valgus wing plate located at the edge of the bottom to align the bottom of the wind tunnel and MSW working surface. The opening bottom covered an area of $400 \mathrm{~mm} \cdot 100 \mathrm{~mm}$ on the MSW surface, whereas the vertical section of the wind tunnel was $100 \mathrm{~mm} \cdot 60 \mathrm{~mm}$. The odour pollutant carried by sweep wind was evenly distributed in the outlet pipe through the decrease pipe, the elbow pipe and the straight outlet pipe. The monitoring site was located at the end of the outlet pipe.

\section{Ambient air sample collection and sampling}

The ambient air samples collected in this research were all sampled and measured at 1.5 metres above the ground. The pollutant concentration at $1.5 \mathrm{me}-$ tres above the ground could accurately reflect the pollutant impact on human activity according to the related standard.

The field tests in this research were arranged in different seasons, and during every testing time, an MSW working surface with an area of 100 square metres was selected as a measurement region. There were three sample sites measured at the same time for each surface wind condition, taking the mean value of the three tests as the measurement result of one certain condition.

Four-time periods in one year were selected for the field test, i.e., spring (April), summer (July), autumn (September) and winter (November). The testing site was the MSW working surface in the Laogang MSW disposal base. The meteorological parameter during the field test are shown in Table $\mathbf{I}$.

\section{Gas sample measurement Odour concentration measurement.}

In this study, a measurement method that combined the Triangle odour bag method and the electronic nose method was used to determine the odour concentration. Each odour sample was determined by the electronic nose in the field. Simultaneously, six gas chambers were used to collect the diffusion odour from the MSW working face according to Chinese government standard No. GB/T 14675. These gas chambers were then sent to a professional testing institution for artificial olfactory discrimination. The measurement results of artificial olfactory discrimination served as learning samples for the electronic nose in the data processing period, based on which an acclimation model was established to transfer the signal tested by the electronic nose into 
TABLE I. METEOROLOGICAL PARAMETERS DURING THE FIELD EXPERIMENT.

\begin{tabular}{lccccccc}
\hline Season & Weather & $\begin{array}{c}\text { Temperature/ } \\
{ }^{\circ} \mathrm{C}\end{array}$ & $\begin{array}{c}\text { Pressure/ } \\
\mathrm{hPa}\end{array}$ & $\begin{array}{c}\text { Humidity/ } \\
\%\end{array}$ & $\begin{array}{c}\text { Temperature } \\
\text { difference between } \\
\text { day and night } /{ }^{\circ} \mathrm{C}\end{array}$ & $\begin{array}{c}\text { Wind } \\
\text { direction }\end{array}$ & $\begin{array}{c}\text { Wind velocity/ } \\
\mathrm{m}^{-1} \mathrm{~s}^{-1}\end{array}$ \\
\hline spring & cloudy & 19.9 & 1009.4 & 80.5 & 8.2 & $\mathrm{SE}$ & 1.9 \\
summer & cloudy & 29.9 & 1001.6 & 74.1 & 5.1 & $\mathrm{SE}$ & 5.6 \\
autumn & cloudy & 20.7 & 1007.5 & 76.8 & 6.4 & $\mathrm{NE}$ & 2.3 \\
winter & overcast & 3.6 & 1028.4 & 71.9 & 4.4 & $\mathrm{NW}$ & 3.9 \\
\hline
\end{tabular}

an olfactory discrimination value. The electronic nose used in this research was the PEN3 electronic nose produced by AIRSENSE, Inc. (Germany). PEN3 consisted of the sensor array (with 10 individual metallic oxide sensors), the flow control system and analysis software. The results of the artificial olfactory discrimination included a dimensionless dilution ratio, which referred to the EU 2003 standard EN13725 "Air quality- determination of odour concentration by dynamic olfactometry", and the odour unit used in this research was $\mathrm{OU} \cdot \mathrm{m}^{-3}$ for calculation convenience (BSI 2003).

\section{VOC measurement}

Due to the complexity and diversity of the MSW odour pollutant, portable PID and FID detectors were used in this research to determine the VOC concentrations. The PID sensor had a sensitive response for aromatic hydrocarbons, ketones, pinenes and parts of organic sulfurs or amines; barely responded for alkanes; and was easily disturbed by high humidity air. The FID sensor was sensitive to hydrocarbons, parts of halogenated hydrocarbons and ketones; was slightly responsive to aldehydes and alcohols; and the impact of air humidity was negligible. The PID detector used in this research was a PGM-7240 PID sensor from the US RAE, Inc., with a measurement range of 0.001 to $200 \mathrm{ppm}$, and used isobutene for the calculation. The FID detector was a micro-FID detector from PHOTOVAC Inc. (USA), with a measurement range of 1 to 50000 ppm, and used methane for the calculation. Isobutene and methane standard gases were respectively used to calibrate the PID and FID detectors each time before the field measurement.

\section{$\mathrm{H}_{2} \mathrm{~S}$ measurement}

The $\mathrm{H}_{2} \mathrm{~S}$ detector was a Jerome $631-\mathrm{X}_{2} \mathrm{~S}$ detector from Arizona Inc. (USA) and had a measurement range of 0.003 to $50 \mathrm{ppm}$. The sensor required regeneration, zero-set and calibration before testing, as well as regeneration following the testing.

\section{Surface source diffusion rate estimation or cal- culation}

The surface source diffusion rate can be expressed as the product of the sample concentration and the flow rate in the sampler:

$\mathrm{SER}=Q \times c / A$

where:

$\mathrm{SER}=$ odour diffusion rate of unit area, $\mathrm{mg} \cdot\left(\mathrm{m}^{2} \bullet \mathrm{s}\right)^{-1}$ or $\mathrm{OU} \cdot\left(\mathrm{m}^{2} \cdot \mathrm{s}\right)^{-1}$

$\mathrm{Q}=$ flow rate of sweep wind, $\mathrm{m}^{3} \cdot \mathrm{s}^{-1}$

$\mathrm{c}=$ odour concentration, $\mathrm{mg} \cdot \mathrm{m}^{-3}$ or $\mathrm{OU} \cdot \mathrm{m}^{-3}$

$\mathrm{A}=$ area covered by the sampler, $\mathrm{m}^{2}$.

\section{RESULTS AND DISCUSSION}

\section{Wind velocity impact on the odour concentration of the ambient atmosphere}

The VOCs were measured by the PID detector (calculated by isobutene) on two measurement sites at the same time, i.e., the MSW working surface and an area 100 metres downwind of the working region, during which time the wind direction was maintained as constant, as shown in Fig. 2:

As shown in Fig. 2, the VOC concentrations in the ambient atmosphere decrease with increasing wind velocity when the conditions of temperature, the MSW component and the operation mode were similar in both the working area and in the downwind area. At the height of 1.5 metres in the working area, the VOC concentrations decrease by $50 \%$ as the wind velocity increases from $3 \mathrm{~m} \cdot \mathrm{s}^{-1}$ to $6 \mathrm{~m} \cdot \mathrm{s}^{-1}$, whereas in the downwind area, a $30 \%$ decrease was observed (100 $\mathrm{m}$ from the working area). The field measurement results indicated that the wind velocity of the ambient atmosphere made a substantial difference on the emission and diffusion of the MSW surface, whereas the wind velocity impact differed between the measurement sites. In this research, the micrometeorological model method was used to calculate 


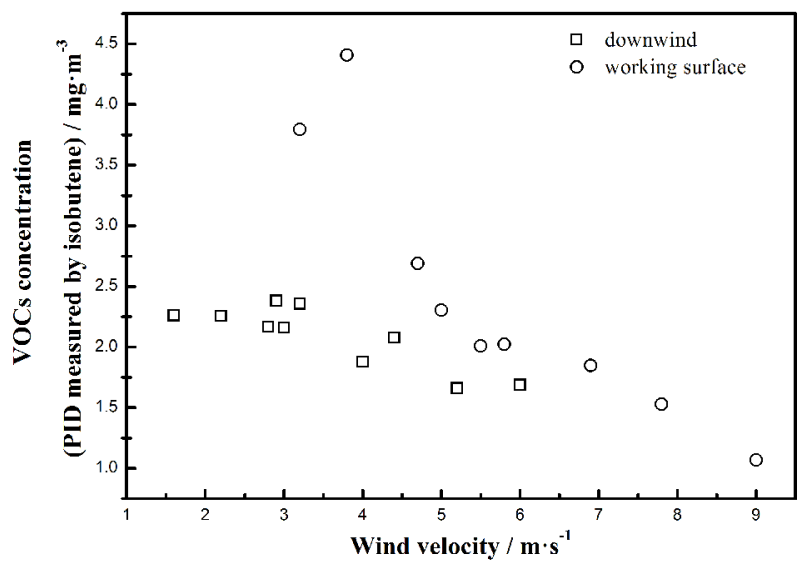

Fig. 2. VOC concentration as a function of wind velocity during landfill operation

the surface source diffusion rate, whereas the arrangement of the sample sites and time length had a considerable impact on the estimation.

\section{Odour pollutant diffusion rate of different seasons and wind velocity VOC emission rate}

In this research, a wind tunnel system was used to measure the odour pollutant diffusion rate of the MSW working surface in three different seasons: spring, summer, autumn and winter. The results are shown as Fig. 3 and Fig. 4.

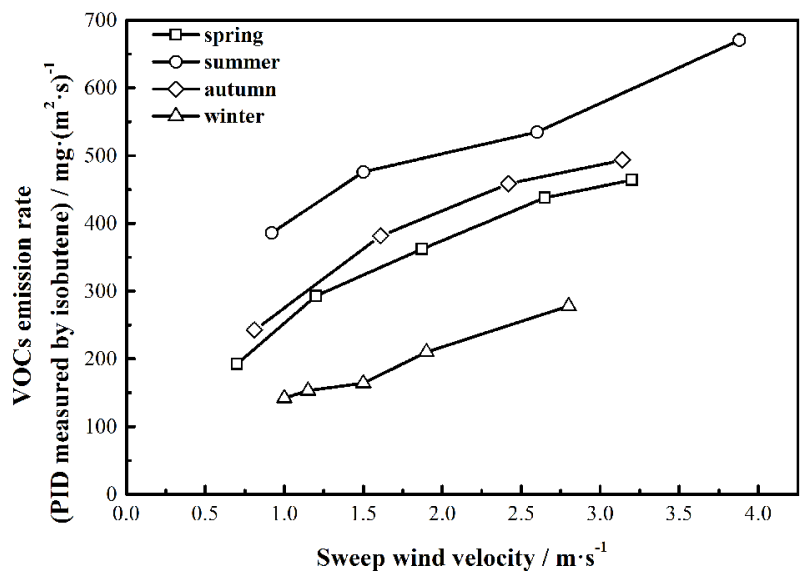

Fig. 3. VOCs emission rate (PID as isobutylene) from the landfill working area

As shown in Fig. 3 and $\mathbf{4}$, in the range of 0.6 to $4 \mathrm{~m} \cdot \mathrm{s}^{-1}$, the VOC emission rate increases with increasing wind velocity. In comparison with the results of spring, summer, autumn and winter, the emission rate of the MSW surface increases with increasing temperature; however, the emission rate measured by the PID detector is far below that measured by the FID detector.

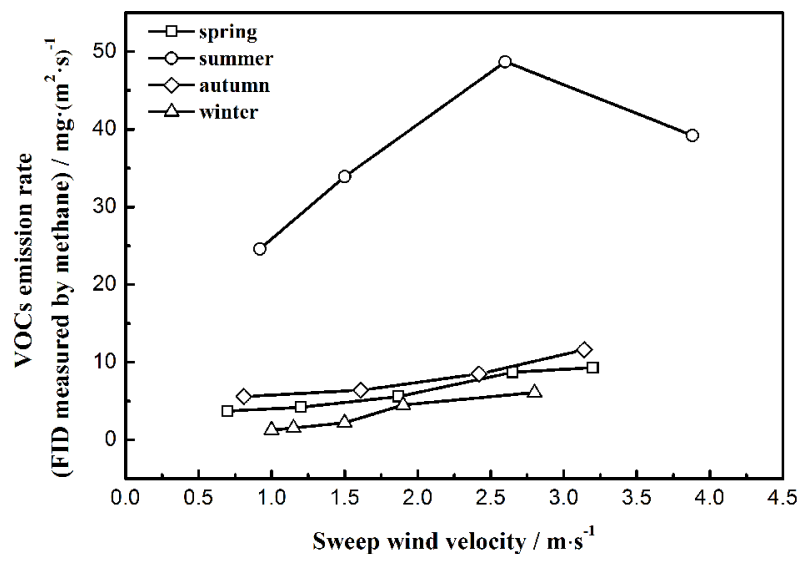

Fig. 4. VOCs emission rate (FID as methane) from the landfill working area

The emission rate of the MSW working surface is different for different components of the odour pollutants. Differences are also noted in terms of how the odour pollutants are transported to the working surface.

The odour pollutants were produced in both aerobic and anaerobic conditions; however, most of the odour gas derives from the anaerobic process. In aerobic conditions, the organic components such as protein will transfer to stimulating ammonia through the aerobic bacteria, whereas in anaerobic conditions, these organic components will be decomposed by the anaerobic bacteria. The decomposition products are incompletely degraded hydrocarbons, hydrocarbon oxygen, some sulfide and nitrogen compounds, such as alkenes, micro-molecular volatile fatty acids, alcohols, aldoketones, mercaptans, alkyl sulfides, amines and amides, and large amounts of methane are produced during the gas phase of the deep anaerobic process for the organic component (Chiriac et al. 2009, Chiriac et al. 2007, Davoli et al. 2003, Dincer et al. 2006, Fang et al. 2012, Lu et al. 2011, Zou et al. 2003). Although the solid component accounts for a large proportion of the MSW, a liquid component also exists, and there is considerable space within the sealed waste bag in the landfill area; therefore, under many circumstances, there are different aerobic or anaerobic processes in different parts of the MSW landfill area, in contrast to a case with relatively 
uniform organic liquid, such as sewage and sludge. The complexity of the degradation process for the MSW landfill working surface is significant, and there are a variety of potential emission metabolites during the degradation process. In general, there are two main origins of odour pollutants. The first is bedding waste that has been landfill compressed, of which the anaerobic proportion is relatively high, and some has entered the anaerobic gas period. The other is the MSW being disposed, which has been collected and transported for 1 or 2 days. The degradation of this MSW depends on the temperature and removal mode (Staley et al. 2006). In summer, the temperature is relatively high, the biochemical reaction rate of the MSW landfill working surface is at a high level because of the high temperature and moisture, and the working surface is generally in the hydrolysis and acid phase. In winter, the temperature is much lower, the biochemical reaction rate of the MSW landfill region is slow, and the working surface is generally in the post-hydrolysis and acid phase.

Odour pollutants are absorbed by liquid and solid substances or diffused out from inside the MSW according to the characteristics of the odour pollutants. The diffusion rate is based on the porosity, the length of the channel and the impetus of the concentration gradient. The diffusion rate of odour pollutants on the MSW landfill working surface is low, whereas the odour concentration on the surface is relatively high when the surface wind velocity is slow. In this case, the impetus of mass transfer is slight, which makes it difficult for the odour pollutant to diffuse, leading to a low surface emission rate. The odour pollutant concentration decreases with increasing surface wind velocity, thereby increasing the concentration gradient between the internal MSW and ambient atmosphere. Simultaneously, the thinning boundary of the laminar layer on the MSW surface leads to a higher mass transfer rate from the inside to the outside, characterized by an increasing emission rate.

The VOCs measured and represented by the PID shown in Fig. 3 are mainly organic compounds and are generated during the prime stage of the aerobic or anaerobic phase, whereas the methane is unresponsive. The FID detector is highly responsive to the hydrocarbons, whereas the oxygen organic compounds are relatively unresponsive. Methane and carbon dioxide make up the main part of landfill gas, with the other components only composing a small proportion (Stayley et al. 2006). The measurement result of the FID detector is generally the reflection of hydrocarbons, including methane. As is shown in Fig. 4, the emission rate measured by the FID detector is approximately two orders of magnitude higher than that measured by the PID detector. In addition, the productivity of methane is at a high level in summer due to the high temperature and anaerobic extent; therefore, the emission rate measured in summer is significantly higher than those in spring, autumn and winter.

In the wind velocity range of $0.6-4 \mathrm{~m} \cdot \mathrm{s}^{-1}$, the emission rate of non-methane VOCs on the MSW landfill working surface in summer is $385-680 \mu \mathrm{g}$ $\left(\mathrm{m}^{2} \cdot \mathrm{s}\right)^{-1}$, whereas in winter, the value is $140-280 \mu \mathrm{g}$ $\left(\mathrm{m}^{2} \cdot \mathrm{s}\right)^{-1}$, which shows a basically linear relationship with the wind velocity.

\section{$\mathrm{H}_{2} \mathrm{~S}$ emission rate}

$\mathrm{H}_{2} \mathrm{~S}$, which is an essential odour pollutant, has been drawing researchers' attention for a long time. In this research, the measurement result of emission rate tested for the MSW landfill working surface is shown in Fig. 5. When the surface wind velocity during the test is in the range of 0.6 to $4 \mathrm{~m} \bullet \mathrm{s}^{-1}$, the $\mathrm{H}_{2} \mathrm{~S}$ emission rate of the MSW working surface increases with increasing wind velocity and temperature. Compared to the VOC result, the $\mathrm{H}_{2} \mathrm{~S}$ emission rate is much lower, i.e., nearly $1 \%$ of the VOC value (measured by the PID and calculated by isobutene). $\mathrm{H}_{2} \mathrm{~S}$ is produced during the deep anaerobic process, and according to the results of foreign researchers, the $\mathrm{H}_{2} \mathrm{~S}$ concentration in landfill gas is approximately $54 \mathrm{mg} \cdot \mathrm{m}^{-3}$, which is almost one in eight thousand to the methane concentration (Powell et al. 2006). In the comparison of Fig. 5 and Fig. 4, the emission rate ratios of $\mathrm{H}_{2} \mathrm{~S}$ and methane on the MSW working surface are similar. In summer, when the wind velocity is in the range of 0.6 to $4 \mathrm{~m} \cdot \mathrm{s}^{-1}$, the

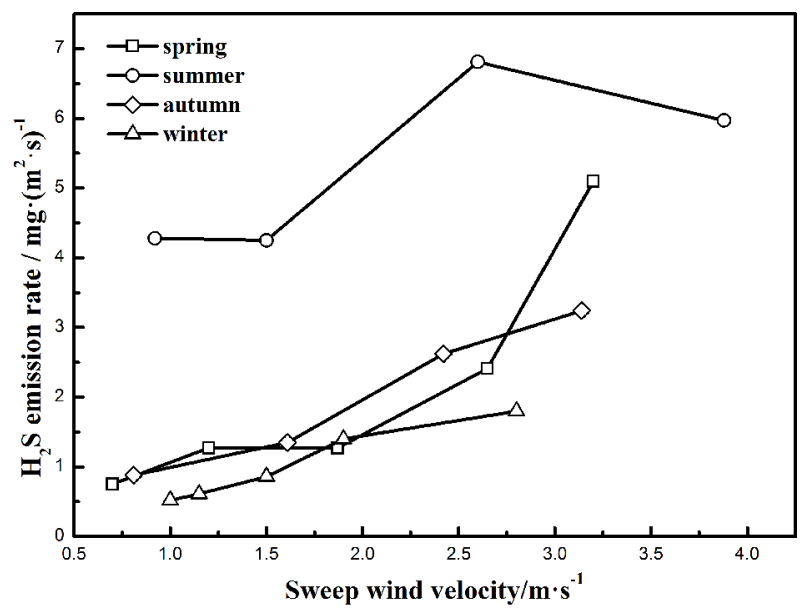

Fig. 5. $\mathrm{H}_{2} \mathrm{~S}$ emission rate from the landfill working area 
emission rate of $\mathrm{H}_{2} \mathrm{~S}$ on the MSW working surface is $4-7 \mu \mathrm{g} \bullet\left(\mathrm{m}^{2} \bullet \mathrm{s}\right)^{-1}$. For a landfill site with an area of 10000 square metres, when the wind velocity is $3 \mathrm{~m}$ $\mathrm{s}^{-1}$ in summer, the emission rate of $\mathrm{H}_{2} \mathrm{~S}$ is $234 \mathrm{~g} \mathrm{~h}^{-1}$.

\section{Odour unit emission rate}

As observed in Fig. 6, when the surface wind velocity of three testing seasons is in the range of 0.6 to $4 \mathrm{~m} \cdot \mathrm{s}^{-1}$, the emission rate of odour pollutants on the MSW landfill working surface is 3.6-141 $\mathrm{OU} \cdot\left(\mathrm{m}^{2} \cdot \mathrm{s}^{-1}\right)$. In general, the variation trend of odour pollutants is similar to those of VOCs and $\mathrm{H}_{2} \mathrm{~S}$, which both show increasing emission rates with increasing temperature and wind velocity. Taking the condition in which, the wind velocity is $2.9 \mathrm{~m} \cdot \mathrm{s}^{-1}$ as an example, the emission rate of odour pollutants at 29 centigrade is 2.3 times higher than that at 20 centigrade and 6.7 times higher than that at 3.6 centigrade. Overall, the odour pollutant emission rate in summer is in the range of 46.5 to $136 \mathrm{OU} \cdot\left(\mathrm{m}^{2} \cdot \mathrm{s}\right)^{-1}$, whereas in winter, the concentration range is 8.516.2 OU $\bullet\left(\mathrm{m}^{2} \bullet \mathrm{s}\right)^{-1}$. Sironi et al. (2005) found that the emission rate of odour pollutants in the working area of the fresh MSW landfill surface is $59 \mathrm{OU} \cdot\left(\mathrm{m}^{2} \cdot \mathrm{s}\right)^{-1}$, whereas the value reported by is $25.91 \mathrm{OU} \bullet\left(\mathrm{m}^{2} \bullet \mathrm{s}\right)^{-1}$; however, both of these results lack considerations of wind velocity data (Sarkar and Hobbs 2003).

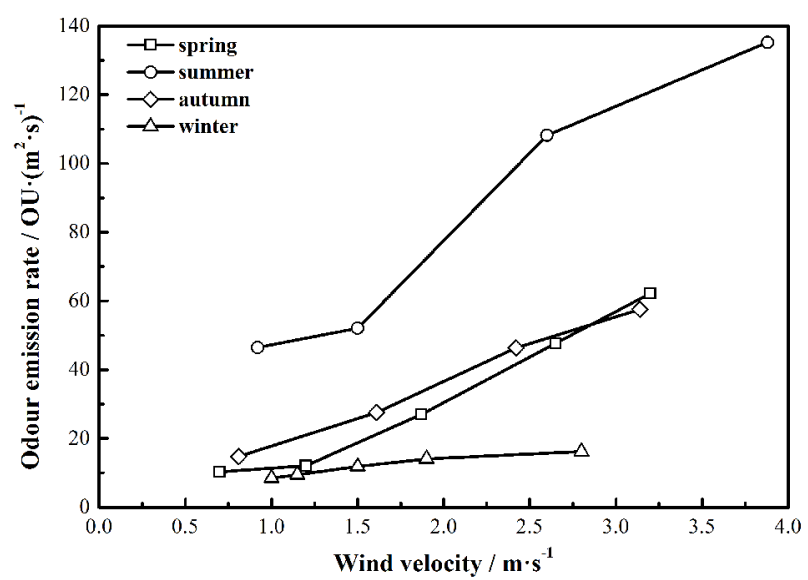

Fig. 6. Odour unit emission rate from the landfill working area

It is indicated from Fig. 6 that the odour pollutant emission rate is approximately linear with the wind velocity in the testing wind condition. The slope of the change curve in summer, autumn or spring is larger than that in winter. The possible reason is the low formation rate of odour pollutants under low temperature conditions. In seasons with high temperature, such as summer, with higher formation and mass transfer rates, the adsorption capacity is relatively low as well, and the growth slope of the emission rate is higher than in the low-temperature seasons. Therefore, it is crucial to reduce the surface wind velocity in high-temperature seasons of summer, autumn and spring to control the emission rate of the MSW landfill working surface.

\section{Impact of ventilation time}

As previously mentioned, in addition to the surface wind velocity, the odour pollutant emission rate of the MSW landfill surface also depends on the odour pollutant content of the MSW and the mass transfer rate; therefore, the measurement area was changed for each working condition. A continuous wind tunnel sweep test was conducted both in winter and summer to determine the emission rate trends for the MSW landfill surface under continuous sweeping wind. The emission rate was measured through the time node, and the result of the growth trends is shown in Fig. 7.

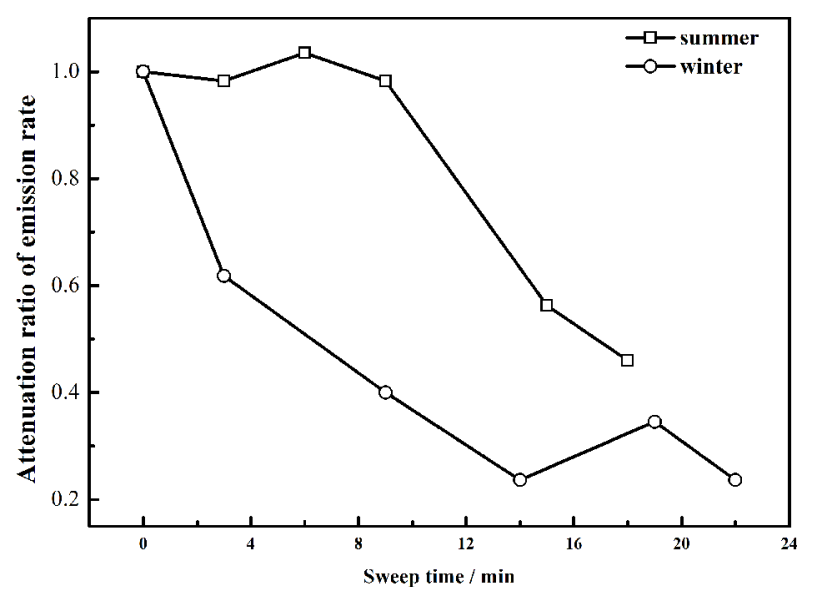

Fig. 7. Effect of sweep time on the odour emission rate

The wind velocity during the measurement in summer is $3.88 \mathrm{~m} \bullet \mathrm{s}^{-1}$ and $1.15 \mathrm{~m} \cdot \mathrm{s}^{-1}$ in winter. As observed in Fig. 7, the odour pollutant emission rate generally decreases with the continuously sweeping surface wind. In summer, the emission rate significantly decreases after 9 minutes of sweeping wind, and the attenuation ratio reaches $39 \%$ after 20 minutes of ventilation. In winter, a decreasing trend occurred from the beginning of the measurement, and the attenuation ratio reaches $76 \%$ after only 15 minutes. Both the decreasing extent and odour pollutant emission rate in summer are less than those 
in winter because the odour pollutant emission rate of the MSW landfill surface is determined by the formation rate of the odour components during the MSW biochemical reactions and the diffusion rate of the odour pollutants. The high temperature in summer leads to a high formation rate of the MSW odour pollutants, high odour content in the MSW, and relatively high diffusion rate; these characteristics cause the emission rate to be higher in the first several minutes of the sweep test and then decrease significantly after 9 minutes. The odour component content and diffusion rate are at relatively low levels in winter, though the temperature and odour concentration of the inner MSW is higher than those on the surface, and the low diffusion rate makes the MSW of the outer layer relatively isolated from the inner part, leading to the instantly decreasing emission rate at the beginning of the test.

The result of the continuous sweep measurement indicates that the emission rate value measured by the fresh-air sweep method refers to the maximum rate, which needs to be corrected when it is used to calculate an average odour concentration of a test longer than 10 minutes. The correction factor is smaller in summer and higher in winter, a characteristic that requires further research.

\section{CONCLUSIONS}

The correlation between the emission rate of VOCs on the MSW landfill working surface with the wind velocity was studied through a wind tunnel sweep test, and the results showed a basically linear relationship with the wind velocity. To be specific, the results show that in the wind velocity range of $0.6-4 \mathrm{~m} \cdot \mathrm{s}^{-1}$, the VOC emission rate was $385-680$ $\mu \mathrm{g} \bullet\left(\mathrm{m}^{2} \cdot \mathrm{s}\right)^{-1}$ in summer and $140-280 \mu \mathrm{g} \bullet\left(\mathrm{m}^{2} \bullet \mathrm{s}\right)^{-1}$ in winter. In addition, the $\mathrm{H}_{2} \mathrm{~S}$ emission rate was also distinct between summer and winter based on the wind tunnel sweep measurements. In the wind velocity range of $0.6-4 \mathrm{~m} \cdot \mathrm{s}^{-1}$, the $\mathrm{H}_{2} \mathrm{~S}$ emission rate in summer was 4-7 $\mu \mathrm{g} \bullet\left(\mathrm{m}^{2} \bullet \mathrm{s}\right)^{-1}$, and it decreased to $0.5-1.8 \mu \mathrm{g} \bullet\left(\mathrm{m}^{2} \bullet \mathrm{s}\right)^{-1}$ in winter.

Based on the results of the wind tunnel sweep measurement, in the wind velocity range of $0.6-4 \mathrm{~m} \cdot \mathrm{s}^{-1}$, the odour pollutant emission rate in summer was $46.5-136 \mathrm{OU} \cdot\left(\mathrm{m}^{2} \cdot \mathrm{s}\right)^{-1}$, whereas in winter, the value was $8.5-16.2 \mathrm{OU} \cdot\left(\mathrm{m}^{2} \bullet \mathrm{s}\right)^{-1}$. The growth rate in summer was higher than in winter. Furthermore, the result of the continuous sweep test indicates that the emission rate value measured by the fresh-air sweep method refers to the maximum rate.

\section{ACKNOWLEDGEMENT}

This paper is supported by Research Project of Scientific and Technological Commission of Shanghai (Grant No.10DZ120010A).

\section{REFERENCES}

BSI. (2003). Air Quality - Determination of Odour Concentration by Dynamic Olfactometry. BS EN 13725. London, U.K.: British Standards Institution.

Capelli L., Sironi S., Del Rosso R. and Céntola P. (2009). Predicting odour emissions from wastewater treatment plants by means of odour emission factors. Water research. 43, 1977-1985.

Capelli L., Sironi S., Del Rosso R., Céntola P. and Grande M.I. (2008). A comparative and critical evaluation of odour assessment methods on a landfill site. Atmospheric Environment. 42, 7050-7058.

Carvalho A.M., Ellis J.T., Lamothe M. and Maia L.P. (2016). Using Wind Direction and Shoreline Morphology to Model Sand Dune Mobilization. Journal of Coastal Research. 32(5), 1005-1015.

Chemel C., Riesenmey C., Batton-Hubert M. and Vaillant H. (2012). Odour-impact assessment around a landfill site from weather-type classification, complaint inventory and numerical simulation. Journal of environmental management. 93, 85-94.

Chiriac R., Carre J., Perrodin Y., Fine L. and Letoffe J.M. (2007). Characterisation of VOCs emitted by open cells receiving municipal solid waste. Journal of hazardous materials. 149, 249-263.

Chiriac R., Carré J., Perrodin Y., Vaillant H., Gasso S. and Miele P. 2009. Study of the dispersion of VOCs emitted by a municipal solid waste landfill. Atmospheric Environment. 43, 1926-1931.

Davoli E., Gangai M.L., Morselli L. and Tonelli D. (2003). Characterisation of odorants emissions from landfills by SPME and GC/MS. Chemosphere. 51, 357-368.

Dincer F., Odabasi M. and Muezzinoglu A. (2006). Chemical characterization of odorous gases at a landfill site by gas chromatography-mass spectrometry. Journal of chromatography A. 1122, 222-229.

El-Fadel M., Findikakis A.N. and Leckie J.O. (1997). Environmental impacts of solid waste landfilling. Journal of environmental management. 50, 1-25.

Fang J.J., Yang N., Cen D.Y., Shao L.M. and He P.J. 2012. Odor compounds from different sources of landfill: characterization and source identification. Waste Management. 32, 1401-1410.

Gao W., Wang Y., Wang W. and Shi L. (2017). The first multiplication atom-bond connectivity index of 
molecular structures in drugs. Saudi Pharmaceutical Journal. 25 (4), 548-555.

DOI: $10.1016 /$ j.jsps.2017.04.021.

Grzeczka G. and Szymak P. (2016). The Hardware Implementation of Demonstrator Air Independent Electric Supply System Based on Pem Fuel Cell. Polish Maritime Research. 23 (4), 84-92.

Halim N.I.A. and Phang I.C. (2017). Salicylic acid mitigates $\mathrm{pb}$ stress in nicotiana tabacum. Science Heritage Journal. 1(1), 16-19.

Hudson N., Ayoko G.A., Dunlop M., Duperouzel D., Burrell D., Bell K., Gallagher E., Nicholas P. and Heinrich N. (2009). Comparison of odour emission rates measured from various sources using two sampling devices. Bioresource technology. 100, 118-124.

Hudson N., Gies A. and Duperouzel D. (2006). Assessment of permeable covers for odour reduction in piggery effluent ponds. 2. Field-scale trials. Bioresource technology. 97, 2015-2023.

Ismail H. and Hanafiah M.M. (2017). Management of End-Of-Life Electrical and Electronic Products: The Challenges and The Potential Solutions for Management Enhancement in Developing Countries Context. Acta Scientifica Malaysia. 1(2), 05-08.

Liu Y., Lu W., Guo H., Ming Z., Wang C., Xu S., Liu Y. and Wang H. (2016). Aromatic compound emissions from municipal solid waste landfill: Emission factors and their impact on air pollution. Atmospheric Environment 139, 205-213.

Liu Y., Lu W., Li D., Guo H., Caicedo L., Wang C., Xu S. and Wang H. (2015). Estimation of volatile compounds emission rates from the working face of a large anaerobic landfill in China using a wind tunnel system. Atmospheric Environment, 111, 213-221.

Lu P., Su Z., Wang G., Dai Z., Zhang Z., Yu C., Liu J., Wang Z., Qin L. and Nie Z. (2011). [VOCs analyzing and odor indicator selecting in ambient air of landfill area]. Huan jing ke xue $=$ Huanjing kexue/[bian ji, Zhongguo ke xue yuan huan jing ke xue wei yuan hui" Huan jing ke xue" bian ji wei yuan hui.] 32, 936-942.

Lu W., Duan Z., Li D., Caicedo J.L.M. Liu Y., Guo H. and Wang H. (2015). Characterization of odor emission on the working face of landfill and establishing of odorous compounds index. Waste. Manag. 42, 74-81.

National Bureau of Statistics of China (NBS). (2015). China Statistical Yearbook 2015. China Statistics Press, Beijing.

Nicolas J., Craffe F. and Romain A.C. (2006). Estimation of odor emission rate from landfill areas using the sniffing team method. Waste Management. 26, 1259-1269.

Pettarin N., Campolo M. and Soldati A. (2015). Urban air pollution by odor sources: Short time prediction. Atmospheric Environment. 122, 74-82.
Powell J., Jain P., Kim H., Townsend T. and Reinhart D. (2006). Changes in landfill gas quality as a result of controlled air injection. Environmental science and technology. 40, 1029-1034.

Prata A.A., Jr. Santos J.M., Beghi S.P., Fernandes I.F., Vom Marttens L.L., Pereira Neto L.I., Martins R.S., Reis N.C. and Jr. Stuetz R.M. (2016). Dynamic flux chamber measurements of hydrogen sulfide emission rate from a quiescent surface A computational evaluation. Chemosphere. 146, 426-434.

Qu C., Wen-Bin D. and Yun G. (2017). Russia Forest Resource Management. Malaysian Journal of Sustainable Agriculture. 1(2), 12-14.

Razali M.A.A. and Said F.M. (2017). Red pigment production by monascus purpureus in stirred-drum bioreactor. Science Heritage Journal. 1(1), 13-15.

Rehman R., Khan A., Rashid H. and Nasir A. (2017). Performance Evaluation of Fly Ash and Red Brick Dust for Recovery of Chromium from Tannery Wastewater by Adsorption Method. Earth Science Pakistan. 1(1), 21-24.

Romain A.C., Delva J. and Nicolas J. (2008). Complementary approaches to measure environmental odours emitted by landfill areas. Sensors and Actuators B: Chemical. 131, 18-23.

Sarkar U. and Hobbs S.E. (2003). Landfill odour: assessment of emissions by the flux footprint method. Environmental Modelling \& Software. 18, 155-163.

Shen Y., Mi W. and Zhang Z. (2017). A Positioning Lockholes Of Container Corner Castings Method Based on Image Recognition. Polish Maritime Research. 24 (SI), 95-101. doi: 10.1515/pomr-2017-0110.

Sironi S., Capelli L., Céntola P., Del Rosso R. and Grande M.I. (2005). Odour emission factors for assessment and prediction of Italian MSW landfills odour impact. Atmospheric Environment. 39, 5387-5394.

Sironi S., Capelli L., Céntola P., Del Rosso R. and Grande M.I. (2006). Odour emission factors for the prediction of odour emissions from plants for the mechanical and biological treatment of MSW. Atmospheric Environment. 40, 7632-7643.

Staley B.F., Xu F., Cowie S.J., Barlaz M.A. and Hater G.R. (2006). Release of trace organic compounds during the decomposition of municipal solid waste components. Environmental science and technology. 40, 5984-5991.

Tan P.F., Hanafiah M.M., Mokhtar M.B. and Harun S.N. (2017). Rainwater Harvesting System: Low Awareness Level Among University Students in a High Rainfall Tropical Country. Malaysian Journal of Sustainable Agriculture. 1(2), 09-11.

Tian H., Gao J., Hao J., Lu L., Zhu C. and Qiu P. (2013). Atmospheric pollution problems and control proposals associated with solid waste management in China: a review. Journal of hazardous materials. 252, 142-154. 
Usman M., Yasin H., Rashid H. and Nasir A. (2017). Quantification of $\mathrm{CO} 2$ Emissions from Vehicles and Possible Remedial Strategies in Faisalabad City. Earth Science Pakistan. 1(1), 17-20.

Van der Weerden T., Moal J., Martinez J., Pain B. and Guiziou F. (1996). Evaluation of the wind-tunnel method for measurement of ammonia volatilization from land. Journal of agricultural engineering research. 64, 11-13.

Vicente-Molina M.A., Fernandez-Sainz A. and IzagirreOlaizola J. (2018). Does gender make a difference in pro-environmental behavior? The case of the Basque Country University students. Journal of Cleaner Production. 176, 89-98.

DOI: $10.1016 /$ j.jclepro.2017.12.079.

Wang X., Jiang J. and Kaye R. (2001). Improvement of a wind-tunnel sampling system for odour and VOCs. Water science and technology: a journal of the International Association on Water Pollution Research. 44, 71-77.

Xiao H., Wang M. and Sheng S. (2017). Spatial evolution of URNCL and response of ecological security: a case study on Foshan City. Geology, Ecology, and Landscapes. 1(3), 190-196.

Ying D., Chuanyu C., Bin H., Yueen X., Xuejuan Z., Yingxu C. and Weixiang W. (2012). Characterization and control of odorous gases at a landfill site: A case study in Hangzhou, China. Waste management. 32, 317-326.
Yun G., Williams S. and Wenbin D. (2017). Water Management of The Mekong River. Malaysian Journal of Sustainable Agriculture. 1(2), 15-17.

Zahan T., Hashem A., Rahman M.M., Bell R.W. and Begum M. (2018). Efficacy of Herbicides in Non-Puddled Transplanted Rice Under Conservation Agriculture Systems and Their Effect on Establishment of The Succeeding Crops. Acta Scientifica Malaysia. 2(1), 17-25.

Zhang D.Q., Tan S.K. and Gersberg R.M. (2010). Municipal solid waste management in China: status, problems and challenges. Journal of Environmental Management. 91, 1623-1633.

Zhao Y., Lu W. and Wang H. (2015). Volatile trace compounds released from municipal solid waste at the transfer stage: evaluation of environmental impacts and odour pollution. Journal of hazardous materials. 300, 695-701.

Zou S., Lee S., Chan C., Ho K., Wang X., Chan L. and Zhang Z. (2003). Characterization of ambient volatile organic compounds at a landfill site in Guangzhou, South China. Chemosphere. 51, 1015-1022. 